untreated cerebral aneurysms: II. Late morbidity and mortality. Ann Neurol 1978;4:418-26.

8 Pool JL. Treatment of arteriovenous malformations of the cerebral hemisphere. I Neurosurg 1962;19:136-41.

19 Crawford PM, West CR, Chadwick DW, Shaw MDM. Arteriovenous malformations of the brain: natural history in unoperated patients. $\mathcal{f}$ Neurol Neurosurg Psychiatry 1986:49:1-10.

20 Federal Regiser 1988,53:3856-89.

20 Federal Register 1988;53:3856-89. 1989;320:1142-3.

22 Meyer CHA, Hitchcock ER. Keeping the score: neurosurgical audit of clinical outcome [Abstract]. I Neurol Neurosurg Psychiatry (in press).

23 Carlson H, Pellettieri L. Doctors' versus patients' evaluation of results after neurosurgery. I Neurol Neurosurg Psychiatry 1989;52:153-5.

24 Roberts CJ, Farrow SC, Charny MC. How much can the NHS afford to spend to save a life or avoid a severe disability? Lancet 1985; i:89-91

25 Buxton M, Acheson R, Caine N, Gibson S, O'Brien B. Costs and benefits of the heart transplant programmes at Harefield and Papworth Hospitals. London: HMSO, 1985. (DHSS research report No 12.)

26 Charny MC, Farrow SC, Roberts CJ. The cost of saving a life through cervical cytology screening: implications for health policy. Health Policy 1987;7: $345-59$.

27 Vermeer F, Simoons ML, de Zuaan C, et al. Cost benefit analysis of early thrombolytic treatment with intracoronary streptokinase. Twelve month follow up report of the randomized multicentre trial conducted by the Interuniversity Cardiology Institute of the Netherlands: Br Heart $f$ 1988;59: Interunis.

$28 \mathrm{Knox}$ EG. Evaluation of a proposed breast cancer screening regimen. $\mathrm{Br} \mathrm{Med} \mathcal{F}$ 1988;297:650-4.

29 Cohadon F. Indications for surgery in the management of Gliomas. Adv Tech Standards Neurosurg 1990;17:189-234.

30 Silfvenius H. Economic costs of epilepsy-treatment benefits. Acta Neurol Scand 1988;78(suppl 117): 136-44.

31 Sandercock PAG, Roberts MA, Blumhardt LD. A prospective audit of the use and costs of myelography in the regional neurosciences unit. $\mathcal{f}$ Neurol Neurosurg Psychiatry 1989;52:1078-84.

32 Thomson JLG. Experiences at the new magnetic resonance imaging centre at Bristol. Br F Radiol 1989;62:134-7.

33 Pickard JD, Murray GD, Illingworth R, et al. Effect of oral nimodipine on cerebral infarction and outcome after subarachnoid haemorrhage: British aneurysm nimodipine trial. Br Med f 1989;298:636-42.

34 Munoz E Sterman H, Patel P, Chaffin D, Mulloy $K$, Wise L. Financial risk, hospital costs, and complications and comorbidity (CCs) in non-CC hospital costs, and complications and comorbidity (CCs) in non-CC stratified neuros

35 Pickard JD, Bailey S, Sanderson H. Steps toward cost-benefit analysis of regional neurosurgical care [Abstract]. I Neurol Neurosurg Psychiatry 1988;51:465.
36 Shaw MDM, Foy P, Conway $M$, et al. Dipyridamole and postoperative ischaemic deficts in aneurysmal subarachnoid haemorrhage. F Neurosurg 1985;63:699-703

37 Pakarinen S. Incidence, aetiology and prognosis of primary subarachnoid haemorrhage. Acta Neurol Scand 1967; suppl 29:1-127.

38 Graf CJ. Prognosis for patients with non surgically-treated aneurysms. Analysis of the cooperative study of intracranial aneurysms and subarachnoid haemorrhage. I Neurosurg 1971;35:438-43.

39 Alvord EC, Loeser JD, Bailey WL, et al. Subarachnoid haemorrhage due to ruptured aneurysms. Arch Neurol 1972;27:273-84.

40 Winn HR, Richardson AE, Jane JA. The long term prognosis in untreated cerebral aneurysms. I. The incidence of late haemorrhage in cerebral aneurysm: a 10-year evaluation of 364 patients. Ann Neurol 1977;1:358-70.

41 Bender MB, Christoff $\mathrm{N}$. Nonsurgical treatment of subdural haematoma Arch Neurol 1974;31:73-9.

42 Gjerris F, Schmidt K. Chronic subdural haematoma-surgery or mannitol treatment. F Neurosurg 1974;40:639-42.

43 Bartlett J. Should chronic subdural haematomas always be evacuated? In: Warlow C, Garfield J, eds. Dilemmas in the management of the neurological patient. Edinburgh: Churchill Livingstone, 1984:215-22.

44 Van den Heever CM, van der Merwe DJ. Management of depressed skull fractures: selective conservative management of non missile injuries. f Neurosurg 1989;71:186-90.

45 EORTC Brain Tumour Group. Misonidazole in radiotherapy of supratentorial malignant brain gliomas in adult patients: a randomized double blind study. Eur f Cancer Clin Oncol 1983;19:39-42.

46 Northfield DW/C. The surgery of the central nervous system. London: Blackwell Scientific, 1973.

47 Gleave JRW. Surgery for primary brain tumours. In: Bleehan NM, ed. Tumours of the brain. Berlin: Springer Verlag, 1986:101-20.

48 Bloom HJG. Treatment of brain gliomas in children. In: Bleehan NM, ed. Tumours of the brain. Berlin: Springer Verlag, 1986:121-40.

49 Post KD, Jackson IMD, Reichlin S. The pituitary adenoma. New York: Plenum Medical, 1980.

50 Simpson D. The recurrence of intracranial meningiomas after surgical treatment. $\mathcal{f}$ Neurol Neurosurg Psychiatry 1957;20:22-39.

51 Mirimanoff ROK, Dosoretz DE, Lingood RM, Ojemann RG, Martuiza RC. Meningioma: analysis of recurrence and progression following neurosurgical resection. F Neurosurg 1985;62:18-24.

52 Weeks $R$. How complete does the removal of an intracranial meningioma have to be? In: Warlow C, Garfield J, eds. 'More dilemmas in the management of the neurological patient. Edinburgh: Churchill Livingstone, 1987:64-70.

53 Sharr MM. Which operation for trigeminal neuralgia? In: Warlow C, Garfield J, eds. Dilemmas in the management of the neurological patient. Edinburgh: Churchill Livingstone, 1984:234-48.

(Accepted 16 fuly 1990)
Unit for Metabolic

Medicine, United Medical and Dental Schools (Guy's Campus), Guy's Hospital, London SE1 9RT

James D Walker, MRCP, research registrar Taimur Tariq, MSC, scientific officer

Giancarlo Viberti, FRCP, professor of diabetic medicine

Correspondence to: Professor Viberti.

BrMed f 1990;301:635-8

\title{
Sodium-lithium countertransport activity in red cells of patients with insulin dependent diabetes and nephropathy and their parents
}

\author{
James D Walker, Taimur Tariq, Giancarlo Viberti
}

Abstract

Objective-To determine whether there are familial and genetic aspects of sodium-lithium countertransport activity in red cells in diabetic nephropathy.

Design-Case-control study.

Setting-Teaching hospital diabetic clinic.

Subjects-40 Patients with insulin dependent diabetes, both of whose parents were alive: 20 with persistent proteinuria and 20 with normal albumin excretion matched for age, duration of diabetes, and body mass index. All 80 parents.

Main outcome measures-Sodium-lithium countertransport activity in red cells and arterial blood pressure.

Results-Sodium-lithium countertransport activity in red cells was higher in the patients with proteinuria than in the patients with normoalbuminuria (mean $(95 \%$ confidence interval) $0.47(0.39$ to 0.54$) v$ $0.33(0.28$ to 0.38$) \mathrm{mmol} / 1 \mathrm{red}$ cells/h respectively, $p=0.0036$; mean difference $0.14(0.04$ to 0.22$)$ ). The mean countertransport activity for the two parents of each patient was calculated, and from this the mean value for each group of parents was calculated; the value was higher in the parents of the patients with proteinuria than in the parents of the patients with normoalbuminuria $(0.40(0.32$ to 0.48$) v 0.30(0.26$ to $0.33) \mathrm{mmol} / \mathrm{l}$ red cells/h respectively, $\mathrm{p}=0.016 ; 0.10$ $(0.02$ to 0.19$))$. Twenty eight of the parents of the patients with proteinuria compared with 12 of the parents of the patients with normoalbuminuria had a countertransport activity that was above the median value in all 80 parents $(p<0 \cdot 001)$. Mean arterial blood pressure in the parents of the patients with proteinuria was related to that of their offspring $(r=0.46 ; p<0.01)$. There was a positive correlation between the sodium-lithium countertransport activity in red cells in the parents and their offspring when all parents and patients were considered $(\mathbf{r}=0.37 ; \mathrm{p}<0.001)$.

Conclusions-Increased sodium-lithium countertransport activity in red cells in the parents of diabetic patients with nephropathy provides further evidence that familial, and possibly genetic, factors related to a predisposition to arterial hypertension have a role in the susceptibility of diabetic renal disease.

\section{Introduction}

The factors that predispose a substantial subset of diabetic patients to the serious complication of diabetic nephropathy have not been elucidated. ${ }^{1}$ Although poor glycaemic control may play some part, it is unlikely to be the sole determinant. ${ }^{2-5}$ Recent work has shown that diabetic nephropathy clusters in families, the frequency of nephropathy in diabetic siblings of diabetic probands with nephropathy being five times that in diabetic siblings of diabetic probands without nephropathy. ${ }^{6}$ The importance of familial factors, and thus possibly heredity, has been further emphasised 
by the finding of a raised arterial pressure in the parents of insulin dependent diabetic patients with proteinuria. ${ }^{78}$ These observations have been complemented by the finding that sodium-lithium countertransport activity in red cells, a marker of risk for essential hypertension, is raised in insulin dependent diabetic patients with either microalbuminuria or established nephropathy. ${ }^{8-10}$ In the general population this countertransport activity is largely genetically determined, ${ }^{11}$ and a positive correlation has consistently been reported between activities in parents and their offspring. ${ }^{12}$

To explore further the familial and hereditary components in the susceptibility to diabetic renal disease we investigated sodium-lithium countertransport activity in the red cells of insulin dependent diabetic patients with and without nephropathy and their parents.

\section{Subjects and methods}

The overnight urinary albumin excretion rate is screened regularly in all patients with insulin dependent diabetes attending our diabetic clinic. All of the patients with persistent proteinuria (defined as an overnight urinary albumin excretion rate $>150 \mu \mathrm{g} / \mathrm{min}$ in at least two consecutive collections in the absence of urinary sepsis, congestive cardiac failure, or any other overt renal disease) and all of those with persistent normoalbuminuria (defined as an overnight urinary albumin excretion rate $<15 \mu \mathrm{g} / \mathrm{min}$ in at least two out of three collections, to exclude persistent microalbuminuria) were asked to complete a family history questionnaire to identify those whose biological parents were both alive.

Twenty patients ( 12 men, eight women) with persistent proteinuria whose biological parents were both alive were identified; they were matched for age, duration of diabetes, and body mass index with 20 patients with normoalbuminuria (nine men, 11 women) whose biological parents were both alive who had been randomly selected from the larger group of diabetic patients with normoalbuminuria. All patients and parents were of European origin, and none of the parents were known to have hyperlipidaemia, thyroid disease, or diabetic nephropathy.

Sixteen of the patients with proteinuria were taking drugs for arterial hypertension, including $\beta$ blockers, calcium antagonists, angiotensin converting enzyme inhibitors, vasodilators, and loop diuretics. None of the patients with normoalbuminuria were taking any drugs other than insulin. Of the 80 parents, 13 were taking antihypertensive drugs, including $\beta$ blockers, calcium antagonists, angiotensin converting enzyme inhibitors, vasodilators, and thiazide and loop diuretics; none of them were taking any oestrogen, progesterone, or amiloride. Three of the parents in each group were known to have diabetes.

All 120 subjects were studied in the morning in the fasting state. The diabetic patients withheld their morning insulin injection until after the procedure, and all subjects (patients and parents) taking antihypertensive drugs were asked to stop them at least 36 hours before the assessment. Subjects were weighed

Details of diabetic patients with and without proteinuria and their parents. Values are means (ranges)

\begin{tabular}{lccccc}
\hline & \multicolumn{2}{c}{ Diabetic patients } & & \multicolumn{2}{c}{ Parents } \\
\cline { 2 - 3 } \cline { 6 - 7 } & $\begin{array}{c}\text { With } \\
\text { proteinuria }\end{array}$ & $\begin{array}{c}\text { With } \\
\text { normoalbuminuria }\end{array}$ & & $\begin{array}{c}\text { Of patients } \\
\text { with } \\
\text { proteinuria }\end{array}$ & $\begin{array}{c}\text { Of patients } \\
\text { with } \\
\text { normoalbuminuria }\end{array}$ \\
\hline No & $12 \mathrm{M}, 8 \mathrm{~F}$ & $9 \mathrm{M}, 11 \mathrm{~F}$ & & $20 \mathrm{M}, 20 \mathrm{~F}$ & $20 \mathrm{M}, 20 \mathrm{~F}$ \\
Age (years) & $31(24-42)$ & $31(18-42)$ & & $62(48-79)$ & $62(42-80)$ \\
Duration of diabetes $($ years $)$ & $20(11-36)$ & $18(10-28)$ & & $27(16-46)$ & $26(19-38)$ \\
Body mass index $\left(\mathrm{kg} / \mathrm{m}^{2}\right)$ & $24(19-31)$ & $24(19-29)$ & &
\end{tabular}

in indoor clothing without shoes, and their height was measured. Blood pressure (phases I and V) in the right arm was measured twice to the nearest $2 \mathrm{~mm} \mathrm{Hg}$ with a standard sphygmomanometer by one observer; measurements were made with the subject supine after 10 minutes' rest. Mean arterial pressure was calculated as the diastolic pressure plus one third of the pulse pressure and the mean of the two measurements used for calculation.

A blood sample was taken from all subjects for measurement of plasma glucose concentration (glucose oxidase method, Yellow Springs Instruments, Yellow Springs, Ohio). Glycated haemoglobin concentration was measured by electroendosmosis (Corning Chemical, Palo Alto, California) in only the diabetic patients. Sodium-lithium countertransport activity in red cells was measured in all subjects as described previously. ${ }^{9}$ Urinary albumin concentration was measured by radioimmunoassay ${ }^{13}$ in timed overnight collections made within three months of the measurement of sodium-lithium countertransport activity in the diabetic patients. Glomerular filtration rate was assessed by clearance of edetic acid labelled with chromium-51 and expressed in $\mathrm{ml} / \mathrm{min} / 1 \cdot 73 \mathrm{~m}^{2} .^{14}$

The study was approved by the hospital's ethical committee.

Student's $t$ test was used to compare normally distributed data, Wilcoxon's rank sum test to compare non-normally distributed data, and $\chi^{2}$ tests with Yates's correction to compare discrete variables. Correlation coefficients were calculated by using the Pearson product moment correlation. ${ }^{15}$

\section{Results}

The patients with and without nephropathy had similar glycaemic control as assessed by the fasting blood glucose concentration (median (range) 11.4 $(2 \cdot 0-19 \cdot 9) \approx 9 \cdot 7(5 \cdot 2-21 \cdot 0) \mathrm{mmol} / \mathrm{l}$ respectively) and glycated haemoglobin concentration $(8 \cdot 5(6 \cdot 5-13 \cdot 5) v$ $(8 \cdot 2(6 \cdot 0-11 \cdot 0) \%)$, but the mean supine blood pressure was higher in the patients with proteinuria (106 $(72-123) v 86(73-100) \mathrm{mm} \mathrm{Hg}, \mathrm{p}<0 \cdot 001)$. By selection the urinary albumin excretion rate was higher in the group with proteinuria (geometric mean 314 (range 170-589) $v 6 \cdot 7(4 \cdot 8-9 \cdot 2) \mu \mathrm{g} / \mathrm{min})$. Similarly, the glomerular filtration rate was lower in the patients with proteinuria (mean $72(15-125) v 127$ $\left.(97-154) \mathrm{ml} / \mathrm{min} / 1 \cdot 73 \mathrm{~m}^{2}\right)$. Age, duration of diabetes, and body mass index were similar in the two groups of patients (table).

The two groups of parents were well matched for age and body mass index (table). Fasting blood glucose concentration was similar in the two groups (mean $5 \cdot 0$ $(4 \cdot 0-13 \cdot 2) \mathrm{mmol} / \mathrm{l}$ in the parents of the patients with proteinuria $v 5 \cdot 0(3 \cdot 2-18 \cdot 7) \mathrm{mmol} / \mathrm{l}$ in the parents of the patients with normoalbuminuria). Mean blood pressure was also similar in the two groups of parents (99 (77-121) v 98 (89-118) $\mathrm{mm} \mathrm{Hg}$ respectively), but more of the parents of the patients with proteinuria were taking antihypertensive treatment (eight $v$ five), though the difference did not achieve significance.

Sodium-lithium countertransport activity in red cells was significantly higher in the patients with proteinuria than in those with normal albuminuria (mean $(95 \%$ confidence interval) $0.47(0.39$ to 0.54$) v$ $0.33(0.28$ to 0.38$) \mathrm{mmol} / \mathrm{l}$ red cells/h respectively, $\mathrm{p}=0.0036$; difference between means $0.14(0.04$ to $0 \cdot 22)$ ). The mean countertransport activity for the two parents of each patient was calculated, and then the mean of these values was calculated for each of the two groups of parents (mid-parental value). The activity was higher in the parents of the patients with proteinuria $(0.40(0.32$ to 0.48$) v 0.30(0.26$ to 0.33$) \mathrm{mmol} / \mathrm{l}$ red cells/h, $\mathrm{p}=0 \cdot 016 ; 0 \cdot 10(0 \cdot 02$ to $0 \cdot 19))$. When all 40 
values obtained in each parental group were considered the mean was still significantly higher in the parents of the patients with proteinuria $(0.40(0.34$ to 0.46$) v 0.30$ $(0.26$ to 0.33$) \mathrm{mmol} / \mathrm{l}$ red cells $/ \mathrm{h}, \mathrm{p}=0.0023 ; 0.10$ $(0.03$ to $0 \cdot 18))$. The median sodium-lithium countertransport activity in red cells in all 80 parents was $0.35 \mathrm{mmol} / \mathrm{l}$ red cells $/ \mathrm{h}$. Twelve of the parents of the patients with normoalbuminuria had values above this (both parents of two patients and one parent of eight patients). In contrast, 28 of the parents of the patients with proteinuria had values above the median (both parents of 10 patients and one parent of eight patients); this difference was highly significant $\left(\chi^{2}=11 \cdot 25 ; p<0.001\right.$; odds ratio $\left.5 \cdot 4\right)$.

There was a significant correlation between blood pressure in the parents of the patients with proteinuria and that in their offspring $(r=0 \cdot 46, p<0 \cdot 001)$. Sodiumlithium countertransport activity in red cells showed a correlation between the parents and their offspring when both groups of parents and patients were considered $(\mathrm{r}=0 \cdot 37 ; \mathrm{p}<0 \cdot 001)$ (figure).

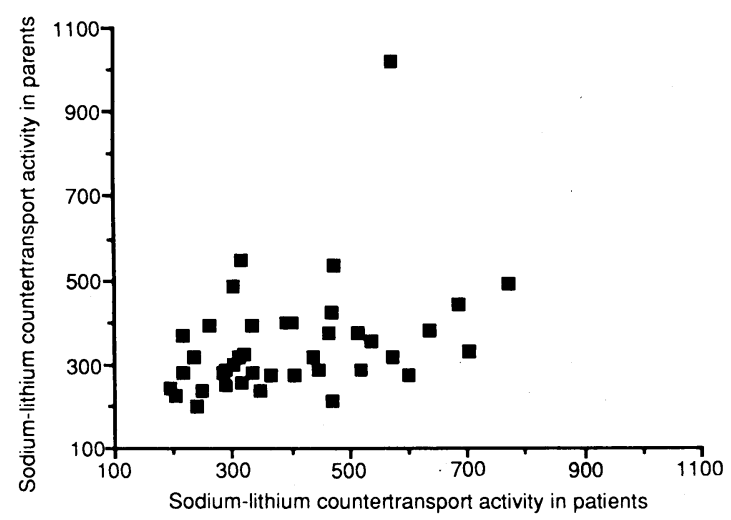

Correlation between sodium-lithium countertransport activity in red cells in 40 diabetic patients and mean value of this activity in each patient's parents (mid-parental value). Values are expressed as mmol/l red cells/h $\left(\times 10^{3}\right)$

\section{Discussion}

The observation that diabetic nephropathy develops in only about one third of patients with insulin dependent diabetes ${ }^{5}$ has led investigators to search for familial, and possibly genetic, factors that may predispose patients to, or protect against, this complication. Recently a familial clustering of diabetic renal disease has been reported ${ }^{6}$ and two studies have suggested that a familial predisposition to arterial hypertension may contribute to the susceptibility to diabetic nephropathy. ${ }^{78}$ Moreover, an increased maximum velocity of the sodium-lithium countertransport in red cells, a marker of risk for essential hypertension, ${ }^{16-18}$ has been shown in patients with insulin dependent diabetes and proteinuria. ${ }^{8-10}$ The contribution of environmental rather than familial or genetic factors to this abnormality of the cell membrane cation transporter, however, remains a matter for debate. ${ }^{19-23}$

Our findings, as well as confirming that sodiumlithium countertransport activity in red cells is increased in diabetic patients with proteinuria, show for the first time that this activity is significantly increased in the parents of these patients, thus strongly supporting the view that familial, and possibly hereditary, elements are centrally important in this phenomenon. In the general population familial aggregation and high hereditability of the sodium-lithium countertransport activity in red cells have been reported. Several studies have estimated that as much as $80-90 \%$ of the individual variance in this activity can be accounted for by inheritance, ${ }^{112}$ and a model with a major gene or a polygenic transmission, or both, has been proposed. ${ }^{11}$ Our data, although obtained from a small sample, seem to support this view of an intermediate form of inheritance. Interestingly, both parents of 10 of the 20 patients with proteinuria but both parents of only two of the 20 patients with normoalbuminuria had a sodium-lithium countertransport activity that was above the median for all 80 parents.

All the parents were white and of similar age and body weight; moreover, none were known to have hyperlipidaemia, diabetic nephropathy, or thyroid disease and none were pregnant. Thus ethnic and environmenal factors that may affect sodium-lithium countertransport activity in red cells ${ }^{19-23}$ are unlikely to have accounted for the observed difference.

Although the overlap in the sodium-lithium countertransport activity in red cells between the two groups of parents and offspring suggests that a raised activity is not the only factor responsible for the development of nephropathy, our findings indicate that a strong familial factor, possibly related to the genesis of arterial hypertension, operates in the susceptibility to diabetic kidney disease.

Arterial blood pressure was similar in the two groups of parents, but a higher proportion of the parents of the patients with proteinuria were taking antihypertensive treatment. The association between the sodiumlithium countertransport activity in red cells and arterial pressure is complex, and recent evidence suggests that increased activity is more specific for a subset of hypertensive patients who are at increased risk of renal and cardiovascular complications, having a family history of hypertensive and cardiovascular disease. ${ }^{24} 25$

The pathogenic mechanism by which a familial, and probably genetic, predisposition to an increased sodium-lithium countertransport activity in red cells contributes to renal disease in diabetes remains to be elucidated. This transporter is believed to be a mode of operation of the physiological sodium-hydrogen antiport, a ubiquitous cell membrane cation transport system that has a role in regulating reabsorption of sodium by renal proximal tubules and growth and reactivity to various vasoactive and growth factors of smooth muscle and mesangial cells. ${ }^{26-30} \mathrm{~A}$ genetically determined hyperresponsiveness of this system, as recently suggested by in vitro studies, ${ }^{31}$ to the hormonal and metabolic disturbances of diabetes, could be implicated in the pathogenesis of the haemodynamic and structural abnormalities associated with arterial hypertension and renal disease in diabetes.

1 Viberti GC, Walker JD. Diabetic nephropathy: etiology and prevention. Diabetes Metab Rev 1988;4:147-62.

2 Krowleski AS, Warram JH, Christlieb AR, Busick EJ, Kahn CR. The changing natural history of nephropathy in type 1 diabetes. Am $\mathcal{F}$ Med $1985 \cdot 78 \cdot 785-94$

3 Deckert T, Poulsen JE. Diabetic nephropathy: fault or destiny? Diabetologia 1981;21:178-83.

4 Watkins PJ, Blainey JD, Brewer DB, et al. The natural history of diabetic renal disease. Qf Med 1972;41:437-56.

5 Andersen AR, Sandhl-Christiansen J, Andersen JK, Kreiner S, Deckert T. Diabetic nephropathy in type 1 (insulin-dependent) diabetes: an epidemiological study. Diabetologia 1983;25:496-501.

6 Seaquist ER, Goetz FC, Rich S, Barbosa J. Familial clustering of diabetic kidney disease. $N$ Engl f Med 1989;320:1161-5.

7 Viberti GC, Keen H, Wiseman MJ. Raised arterial pressure in parents of proteinuric insulin-dependent diabetics. Br Med f 1987;295:515-7.

8 Krolewski AS, Canessa M, Warram JH, et al. Predisposition to hypertension and susceptibility to renal disease in insulin-dependent diabetes mellius. NEngl F Med 1988:318:140-5.

9 Mangili R, Bending JJ, Scott G, Li LK, Gupta A, Viberti GC. Increased sodium-lithium countertransport activity in red cells of patients with sodium-lithium countertransport activity in red cells of patients with
insulin-dependent diabetes and nephropathy. $N$ Engl f Med 1988;318: $146-50$

10 Jones SL, Trevisan R, Tariq T, et al. Sodium lithium countertransport activity is increased in microalbuminuric diabetics. Hypertension 1990;19:570-5.

11 Hasstedt SJ, Wu LL, Ash KO, Kuida H, Williams R. Hypertension and sodium-lithium countertransport in Utah pedigrees: evidence for major locus inheritance. Am $\mathcal{F}$ Hum Genet 1988;43:14-22.

12 Boerwinkle E, Turner ST, Weinshiliboum R, Johnson M, Richelson W, Sing 
CF. Analysis of the distribution of erythrocyte sodium-lithium countertransport in a sample representative of the general population. Genet Epidemiol 1986;3:365-78.

13 Keen H, Chlouverakis G. An immunoassay for urinary albumin at low concentrations. Lancet 1963;ii:913-6.

14 Chantler C, Garnett ES, Parsons V, Veall N. Glomerular filtration rate measurement in man by the single method using "CrEDTA. Clin $S$ 1969;37:811-3.

15 Ryan BF, Joiner BL, Ryan TA Jr. Correlation and regression. In: Ryan BF, Joiner BL, Ryan TA Jr, eds. Minitab handbook. 2nd ed. Boston: Duxbury Press, 1985:218-36.

16 Canessa M, Adragna N, Solomon HS, Connolly B, Tosteson DC. Increased sodium-lithium countertransport in red cells of patients with essential hypertension. N Englf Med 1980;302:772-6.

17 Hilton PJ. Cellular sodium transport in essential hypertension. $N$ Engl $\mathrm{G} \mathrm{Med}$ 1986;314:222-9.

18 Williams RR, Hunt SC, Wu LL, Hasstedt SJ, Hopkins PN, Ash KO. Genetic and epidemiological studies on electrolyte transport systems in hypertension. Clin Physiol Biochem 1988;6: 136-49.

19 Erdmann E, Schmidinger U. Oubain sensitive and insensitive cation transport in normo- and hypertensives in hyperkalaemic states. In: Villareal $\mathrm{H}_{\text {, }}$ Sambhi MP, eds. Topics in pathophysiology of hypertension. Boston: Martinus Nijhoff, 1984:162-71.

20 Canessa M, Bize I, Solomon $\mathrm{H}$, et al. Na transport and co-transport in human red cells; function, dysfunction and genes in essential hypertension. Clin Exp Hypertens 1981:3:783-95.

21 Woorley RJ, Hentschell WM, Cormier C, et al. Increased sodium-lithium countertransport in erythrocytes of pregnant women. $N$ Engl $7 \mathrm{Med}$ 1982;307:412-6.

22 Brent GA, Canessa M, Dluhy RG. Reversible alteration of red cell sodium- lithium countertransport in patients with thyroid disease. $f$ Clin Endocrinol Metab 1989;68:1-7.

23 Corrocher R, Steinmayer M, Ruzzenente $\mathrm{O}$, et al. Elevation of red cell sodiumlithium countertransport in hyperlipaemias. Life Sci 1985;36:649-55.

24 Morgan DB, Stewart AD, Davidson C. Relations between erythrocyte lithium efflux, blood pressure and family histories of hypertension and cardiovascular disease. Studies in a factory workforce and a hypertension clinic. vascular disease. Studies in

25 Carr SJ, Thomas TH, Wilkinson R. Erythrocyte sodium-lithium countertransport in primary and renal hypertension and relation to family history. Eur $\mathcal{F}$ Clin Invest 1989;19:101-6.

26 Mahnensmith RL, Aronson PS. The plasma membrane sodium-hydrogen exchanger and its role in physiological and pathophysiological processes. Circ Res 1985;56:773-8.

27 Semplicini A, Spalvins A, Canessa M. Kinetics and stoichiometry of the human red cell $\mathrm{Na}+/ \mathrm{H}+$ exchanger. $f$ Membr Biol 1989;107:219-28.

28 Canessa M, Morgan K, Semplicini A. Genetic differences in lithium sodium exchanger and the regulation of sodium hydrogen exchange in essential hypertension. 7 Cardiovasc Pharmacol 1988;12 (suppl 3):S92-8.

29 Weder AB. Red cell sodium-lithium countertransport and renal lithium clearance in hypertension. $N$ Engl F Med 1986:314:198-201.

30 Smith JB, Brock TA. Analysis of angiotensin-stimulated Na transport in cultured smooth muscle from rat aorta. I Cell Physiol 1983;114:284-90

31 Li LK, Trevisan R, Walker JD, Viberti GC. Overactivity of sodium-hydrogen antiport and enhanced cell growth in fibroblasts of type 1 (insulindependent) diabetics with nephropathy [Abstract]. Kidney Int 1990;37: 199A.

(Accepted 25 fuly 1990)

\title{
Prediction of hip fracture in elderly women: a prospective study
}

\author{
R W Porter, C G Miller, D Grainger, S B Palmer
}

Abstract

Objective-To assess the relative importance of osteoporosis of the os calcis, cognisance, and mobility in the risk of subsequent fracture of the hip in elderly women.

Design-Prospective study of elderly women in residential care over two years.

Setting-21 Private or 38 local authority residential homes for the elderly and 4 geriatric hospitals in Doncaster and Hull.

Subjects-1414 Ambulant women aged over 69, in private or local authority residential care or geriatric care. Those who had had bilateral hip surgery were excluded.

Main outcome measures-Broad band ultrasonic attenuation (BUA) index, Clifton assessment procedures for the elderly test (for cognisance), and mobility on a six point scale, and fracture of the hip in the subsequent two year period.

Results - 73 Women fractured their hip during the two years. Their mean age was not significantly different from that of the women who did not have a fracture (85.3 (SD 5.6) $v 83.9(6.3) ; \mathrm{p}=0.07$ ), but their mean BUA index $(40.3(19.3) v 50.9(22.2)$ $\mathrm{db} / \mathbf{M H}_{2}$ ), and score for cognisance (median 19 (interquartile range $10 \cdot 5-27 \cdot 0) v 24(17-30)$ ) were significantly lower (both $\mathrm{p}<\mathbf{0 \cdot 0 0 1}$ ). These variables had independent associations with fracture of the hip. Women with fractures had a significantly lower score for the psychomotor component of the cognisance test $(4.5(1-8) v 7(2-10) ; p<0.0025$ and were significantly more mobile $(1(1-3) v 3(1-6) ; \mathrm{p}<0.02)$. Subdividing women according to high, medium, and low scores for BUA index and cognisance testing disclosed a high risk group (118 women) with low BUA index and cognisance score, whose incidence of fracture was $12.8 \%$; in the group at lowest risk (136 women) with high BUA index and cognisance score, the incidence of fracture was only $1.5 \%$ (relative risk $8.4(95 \%$ confidence interval -2.0 to 35.5$)$ ). Further analysis showed that those most at risk were, additionally, most mobile but that less mobile women with good cognisance had a low incidence of fractures, regardless of the BUA index, $(1 \cdot 2 \%$, high index, $v 0.9 \%$, low index).
Conclusions - Elderly women most at risk of sustaining hip fractures were those with low BUA index, low cognisance test score, and high mobility. Improving bone strength and cognisance in elderly women may reduce their incidence of hip fracture.

\section{Introduction}

About a fifth of orthopaedic beds are occupied by patients with fracture of the hip. ${ }^{1}$ The incidence has doubled in the past 25 years, and as the number of elderly people in the population continues to increase there is justifiable concern about this modern orthopaedic epidemic. ${ }^{2}$ Retrospective studies suggest that osteoporosis is a risk factor for hip fracture ${ }^{34}$ but the propensity to fall and the neuromuscular response may be equally important. ${ }^{5}$

We conducted a prospective study in a population of 1414 elderly women in residential care to assess the relative importance of osteoporosis (measured by a new ultrasound technique), cognisance, and mobility as risks for subsequent fracture.

\section{Subjects and methods}

We invited women aged 70 or above living in private residential homes or local authority homes for the elderly or in geriatric care within the catchment areas of Doncaster and Hull Royal Infirmaries to participate in the study. Women who were unable to walk with assistance and those who had had previous bilateral hip surgery were excluded.

Broad band ultrasonic attenuation (BUA) of the os calcis was used to assess osteoporosis with an Osteosonics Ultrasonic Bone Analyser $1001 .^{6}$ The foot was placed in a water bath and seated on a heel plate. An anthropometric ankle measurement ensured that the os calcis was centred between transmitting and receiving ultrasound transducers. By subtracting a water trace it was possible to measure in decibels a linear increase in ultrasonic attenuation with increasing frequency over the range 0.2 to $0.6 \mathrm{MHz}$. The rate of increase of attenuation (in $\mathrm{dB} / \mathrm{MHz}$ ) was used as the index of assessment and is referred to hereafter as the BUA index. The technique is portable, 